\title{
Global Companies and Global Regulation
}

\author{
Luca Bisio*
}

\begin{abstract}
In a global economy, corporate responsibility has to interact with the specific social and environmental aspects of each Nation-State, which consequently are not viewed as local differences but rather as elements of market competition.

This interaction has to concentrate on complex matters such as profitability and the protection of financial equilibriums, respect for ethical codes, environmental concerns and social profiles in general.
\end{abstract}

Keywords: Global Companies; Global Regulation; Nation-States; Corporate Governance; Corporate Responsibility, Ethical Codes; Global Markets

\section{The Market Globalisation Process}

Following researchers describing scarcity economies, numerous studies into competitive dynamics then concentrated in over-supplied markets. These phenomena, summed up by the term globalisation, have been analysed from countless points of view .

Globalisation may be defined as a 'set of interrelated processes putting people, groups, communities, nations, markets, large companies, and international organisations (governmental and non-governmental) into contact in complex webs of social relations, .

These processes are generated by interconnected factors such as:

- the radical change in world politics, with the fall of the Berlin wall and simultaneous crises in managed economies and in relation to protectionist policies;

- the spread of new information and communication technologies, linked to a sharp drop in the costs of such technologies;

- the growth of a global economic-financial market and parallel liberalisation, deregulation, and privatisation policies;

- the creation of a global village in which the media have ever greater personalised communication tools applied to specific targets;

- mass immigration to economies with over-supply.

In this evolutionary context, the global economy may be considered a system in

*Lecturer in Management, University of Milan-Bicocca (luca.bisio@unimib.it)

Bisio Luca, Global Companies and Global Regulation, Symphonya. Emerging Issues in Management (symphonya.unimib.it), n. 1, 2005, pp. 87-101 
which 'strategically dominant companies act as a unit at the planetary level in real or potentially real time, ${ }^{3}$, while factors that are not considered efficient are excluded due to their structural irrelevance. This creates a continuously evolving context that might be called the 'flow society', i.e., 'a society in which the real basis of all processes consists of flows (financial, technological, images and information), in which power and wealth are organised into global networks that convey flows ${ }^{4}$. These flows are asymmetrical and express power relationships amongst global players.

\section{Corporations and Globalisation Processes}

Multinationals play a primary role in 'running' the flow society. When trying to define their essential aspects, it is important not to concentrate only on the negative aspects of their actions, but rather to highlight some of the positive elements that have allowed them to operate globally.

First, these companies are among the few organisations able to simultaneously cross all of the globalisation thresholds, in particular the:

- $\quad$ size threshold: they are international and go beyond national borders;

- time threshold: they follow long-term strategies, using measurements different from those used in politics, government or education;

- complexity threshold: they efficiently manage differences, multiple mindsets, risk and resource development, and quickly adapt to continuously changing environments;

- information and communication threshold: they are linked to the world and act effectively and rapidly ${ }^{5}$.

They have taken actions based on synergetic and harmonic growth policies, such as:

- mergering (mergers, acquisitions, joint ventures, alliances, etc.), aimed at optimising competitive relationships;

downsizing, aimed at achieving a leaner and more responsible organisation by means of targeted selection of personnel, outplacement, the switch from country managers to key product managers and category managers, etc ${ }^{6}$.

Moreover, multinationals immediately understood the importance of intangible assets both at the product level (pre- and after-sales service, logistics, merchandising, design, packaging, etc.) and at the corporate level (corporate culture, ICT system, brand equity ${ }^{7}$ ) - essential elements for controlling the volatile demand that is typical of markets in over-supply. Global size, strategic vision, organisational and operative flexibility, and emphasis on intangible assets have allowed these corporations to achieve amazing performance in a dynamic, competitive system governed by market-space competition ${ }^{8}$ and time-base competition principles.

Nevertheless, along with these positive elements describing the corporate path to globalisation, we find others that point out the need for regulation and corporate governance. The over-supply that now characterises the richest markets has thrust multinationals into a 'neo-liberal' spiral, understood as a frenetic search for markets 
to satisfy with minimum production and marketing costs by means of intensive, irrational, and at times socially wasteful exploitation of basic production factors (capital, labour and natural resources) ${ }^{9}$. One of the critical elements generated by this phenomenon is the growing separation of production/supply sites and sale/delivery sites. Given the loosening of territorial ties, this allows companies to take advantage of differences amongst countries and, from time to time, to benefit from the best conditions. But such conditions often mean less worker protection, extremely permissive environmental regulations, health and hygiene conditions incompatible with western standards, etc.

It is also standard practice (justified by the need to contain costs) not to locate production at a fixed site, which often creates significant consequences for local employment $^{10}$ More precisely, 'economic logic - which guides a company's decentralised growth across global markets - induces it to move dynamically in order to rapidly seize advantageous opportunities from various locations. For a company operating in over-supply, the concept of localisation choice is no longer valid due to the temporary nature of the advantage offered by a location and, consequently, to the company's propensity to change location. On the other hand, the expression 'cost effectiveness assessment of a production site' regards guidelines that are necessarily dynamic. A company tends to reduce its organisation in unstable markets, freeing it as much as possible from obligations that limit its scope of action. Therefore, a company adapts not only via flexibility in relation to production, but also via the dynamic management of localisation ${ }^{11}$.

There are at least two equally significant consequences in addition to those deriving from localisation choices and from the separation of production and sales sites. The first is that multinationals have usurped the normal decision-making roles of Nation-States. Companies have access to such extensive and sophisticated market data that they often compete with governments in setting guidelines for local development. They 'have ever greater access to knowledge resulting from their enormous efforts in research and development. They decide what research to conduct and thus what products and services to sell. Obviously, they do this on the basis of market data, and one might think this is the best way to allocate resources. But this is true only in part: the invisible hand serves only liquidity producing needs. As we have seen, the criteria are purely commercial and financial. Take pharmaceutical studies for example: due to a solvent market, these studies do not promote the discovery of drugs to cure diseases in poor nations (orphan drugs); instead, much more money is invested to study obesity and impotence occurring in rich countries ${ }^{12}$.

The second regards the risk of over-emphasis of short-term goals by companies that 'often attempted to satisfy shareholder expectations, with frequent prevalence of orientation toward profit, with behaviours at times creating disparate treatment amongst subgroups of risk capital contributors (for example, between majority and minority shareholders ${ }^{13}$ ). This behaviour generates the double risk of not ensuring conformity to economic principles (most commonly, only putting in quarterly report results that are crucial for share performance on the stock market) and of increasing inequality amongst shareholders by means of practices such as:

- boards of directors composed of members chosen only by shareholders (primarily majority shareholders) and management based on political favours, ready to ratify decisions reached previously and to sign minutes 
written previously;

- situations of asymmetry of informational/communicational, with the issuance of extremely concise, vague, or opportunely manipulated messages;

- collusive relationships between top management and banks aimed at transferring risk to less well-informed operators, who thus become the weakest (and often losing) link in the chain ${ }^{14}$.

\section{The Supranational Response by Nation-States}

As a result of the above-described behaviour, multinationals have been severely criticised due to their insensitivity to such matters as the environment, proper nutrition, worker protection and social inequality. This has caused competitive fractures amongst organisations placed at different levels with regard to specific interests, especially:

- corporations at the transnational level;

- governments at the local and international level (with independent and distinct jurisdiction);

- institutions that regulate competition (such as Antitrust Commissions, Central Banks, etc. ${ }^{15}$ );

consumer associations, non-governmental organisations, movements for ethical and responsible consumption ${ }^{16}$.

This situation has also created a role crisis for Nation-States that are structurally weak for two reasons. First, their breadth of authority is insufficient to control global flows and their organisations are generally too rigid to adapt to the constantly changing global system (especially if compared to the responsiveness and flexibility of multinationals). Second, the multiplicity of territorial parties that want to be represented by Nation-States generates conflicts that tend to delegitimise the very idea of national representation. In essence, it becomes harder and harder for Nation-States to link the global system to local socio-economic systems ${ }^{17}$.

As a result, the rhythm of technical-economic change imposed by globalisation is often quicker than that of political, civil and institutional society. Administrative, social and educational systems have been unable to keep pace, and this gap has had a great influence on inequality, exclusion, dissociation and social matters ${ }^{18}$. This role crisis may be considered the consequence of a series of concurrent causes that may be summarised as follows:

- the impossibility of fully governing economic policies;

- heavy dependence on global financial markets and flows of foreign capital;

- the impossibility of ensuring legitimisation by means of traditional welfare policies, no longer sustainable from an economic-financial point of view (especially in EU Member Nations ${ }^{19}$ );

- progressive loss of control over media and information flows due to the globalisation and interwoven ownership of media (which thereby elude control by individual states), the flexibility and pervasiveness of technologies (which makes complete regulation and control of information impossible), and to the independence and variety of media; 
- globalisation of organised crime, with increased infiltration into state organisations and greater impact of illegal financial flows on the entire economy of a Nation-State ${ }^{20}$.

To achieve greater negotiating power and overall solidity, states have attempted (in collaboration with supranational organisations) to define guidelines for companies and for individual Nation-States regarding matters of general interest. One important initiative was the Global Compact launched by UN Secretary General Kofi Annan, which sought to create a partnership of the UN, multinationals, the ILO (International Labour Organisation), non-governmental organisations, and Amnesty International ${ }^{21}$. The Compact, announced at the World Economic Forum in Davos in January 1999 and formally presented at the UN in July 2000, is a voluntary project that provides a global context to promote sustainable growth and a sense of citizenship by means of committed and creative corporate leadership ${ }^{22}$.

The Compact promotes:

- the protection of human rights: 1. Businesses should support and respect internationally proclaimed human rights within their sphere of influence; 2. Businesses should make sure they are not complicit (even indirectly) in human rights abuses.

- the respect of labour standards: 3. Businesses should uphold the freedom of association and the effective recognition of the right to collective bargaining; 4. Businesses should uphold the elimination of all forms of forced and compulsory labour; 5. Businesses should uphold the effective abolition of child labour; 6. Businesses should uphold the elimination of discrimination with respect to employment and occupation; 7. Businesses should support a precautionary approach to environmental challenges;

- the development of environmental responsibility: 8. Businesses should undertake initiatives to promote greater environmental responsibility; 9. Businesses should encourage the development and promotion of environmentally friendly technologies;

- the fight against corruption: 10. Businesses should work against corruption in all its forms, including extortion and bribery.

The following table describes transnational initiatives that have anticipated or implemented the principles promoted by the Global Compact (Table 1).

Table 1: Supranational Global Initiatives

\begin{tabular}{|c|c|c|c|c|}
\hline INITIATIVE & APPROACH & $\begin{array}{l}\text { CONTENTS, } \\
\text { PRINCIPLES, } \\
\text { RULES }\end{array}$ & $\begin{array}{l}\text { STRONG } \\
\text { POINTS }\end{array}$ & $\begin{array}{l}\text { WEAK } \\
\text { POINTS }\end{array}$ \\
\hline $\begin{array}{l}\text { I.L.O. } \\
\text { Declaration on } \\
\text { Fundamental } \\
\text { Principles and } \\
\text { Rights at } \\
\text { Work and } \\
\text { subsequent } \\
\text { reports }\end{array}$ & $\begin{array}{l}\text { Regulatory, } \\
\text { with } \\
\text { guidelines for } \\
\text { monitoring } \\
\text { and legal } \\
\text { action against } \\
\text { violators. }\end{array}$ & $\begin{array}{l}\text { Fundamental } \\
\text { principles: } \\
\text { - proper pay and } \\
\text { working hours } \\
\text { - supplementary } \\
\text { pay and overtime; } \\
\text { - right to work } \\
\text { and to keep one's }\end{array}$ & $\begin{array}{l}\text { - States that } \\
\text { have not } \\
\text { ratified the } \\
\text { Declaration } \\
\text { are still } \\
\text { obliged to } \\
\text { respect the } \\
\text { principles of }\end{array}$ & $\begin{array}{l}\text { - Weak legal } \\
\text { action } \\
\text { - Individual } \\
\text { companies are } \\
\text { not named } \\
\text { - Very long } \\
\text { technical time- } \\
\text { fames }\end{array}$ \\
\hline
\end{tabular}




\begin{tabular}{|c|c|c|c|c|}
\hline (1998) & & $\begin{array}{l}\text { job; } \\
\text { - day of rest and } \\
\text { paid leave; } \\
\text { - freedom of } \\
\text { thought, } \\
\text { conscience, and } \\
\text { religion }\end{array}$ & $\begin{array}{l}\text { fundamental } \\
\text { rights. } \\
\text { - Formal } \\
\text { procedures for } \\
\text { complaints }\end{array}$ & \\
\hline $\begin{array}{l}\text { OECD } \\
\text { Guidelines for } \\
\text { multinational } \\
\text { enterprises } \\
(2000)\end{array}$ & $\begin{array}{l}\text { Voluntary, } \\
\text { not binding } \\
\text { on } \\
\text { companies, } \\
\text { but states are } \\
\text { obliged to } \\
\text { create } \\
\text { organisations } \\
\text { (National } \\
\text { Points of } \\
\text { Contact) to } \\
\text { bring legal } \\
\text { action against } \\
\text { multinationals } \\
\text { that do not } \\
\text { respect non- } \\
\text { binding } \\
\text { regulations. }\end{array}$ & $\begin{array}{l}\text { General } \\
\text { principles } \\
\text { (promote } \\
\text { economic, social } \\
\text { and } \\
\text { environmental } \\
\text { progress to create } \\
\text { sustainable } \\
\text { growth) and rules } \\
\text { on: } \\
\text { - publication of } \\
\text { information; } \\
\text { - employment } \\
\text { and industrial } \\
\text { relations; } \\
\text { - environment } \\
\text { and fight against } \\
\text { corruption; } \\
\text { - consumer } \\
\text { interests; } \\
\text { - science and } \\
\text { technology, } \\
\text { competition and } \\
\text { tax system. }\end{array}$ & $\begin{array}{l}\text { - Examines } \\
\text { conduct of } \\
\text { multinationals } \\
\text { in foreign } \\
\text { countries. } \\
\text { - It is the only } \\
\text { international } \\
\text { body by which } \\
\text { society can } \\
\text { present } \\
\text { complaints } \\
\text { against } \\
\text { practices by } \\
\text { multinationals. }\end{array}$ & $\begin{array}{l}\text { - Does not talk } \\
\text { about working } \\
\text { hours or } \\
\text { minimum } \\
\text { wages. } \\
\text { - Does not } \\
\text { consider } \\
\text { I.L.O. } \\
\text { conventions. } \\
\text { - Opinions of } \\
\text { NPCs not } \\
\text { binding, no } \\
\text { penalty. } \\
\text { - Low level of } \\
\text { standards and } \\
\text { weak } \\
\text { monitoring } \\
\text { system. }\end{array}$ \\
\hline $\begin{array}{l}\text { U.N. } \\
\text { Global } \\
\text { Compact } \\
\text { Project }\end{array}$ & Voluntary & $\begin{array}{l}\text { - Four areas of } \\
\text { principles: human } \\
\text { rights, work, } \\
\text { environment, } \\
\text { fight against } \\
\text { corruption. } \\
\text { - Four tools to } \\
\text { encourage } \\
\text { membership: } \\
\text { dialogue, forum } \\
\text { to pool } \\
\text { knowledge, } \\
\text { projects amongst } \\
\text { various partners, } \\
\text { local networks }\end{array}$ & $\begin{array}{l}\text { - Active } \\
\text { participation } \\
\text { by many } \\
\text { parties in } \\
\text { discussion } \\
\text { generating } \\
\text { policies and } \\
\text { resolutions to } \\
\text { be adopted. } \\
\text { - } \\
\text { Representation } \\
\text { of companies, } \\
\text { labour } \\
\text { organisations, } \\
\text { social } \\
\text { organisations } \\
\text { and }\end{array}$ & $\begin{array}{l}\text { - Acceptance } \\
\text { procedures not } \\
\text { subject to } \\
\text { investigation; } \\
\text { - No } \\
\text { subsequent } \\
\text { checks on } \\
\text { actual conduct } \\
\text { of member } \\
\text { companies. }\end{array}$ \\
\hline
\end{tabular}




\begin{tabular}{|c|c|c|c|c|}
\hline & & & $\begin{array}{l}\text { governments } \\
\text { of various } \\
\text { nations. } \\
\text { - Intends to } \\
\text { translate } \\
\text { general } \\
\text { principles into } \\
\text { concrete } \\
\text { actions and } \\
\text { real changes. }\end{array}$ & \\
\hline $\begin{array}{l}\text { U.N. } \\
\text { (Division for } \\
\text { sustainable } \\
\text { development) } \\
\text { Agenda } 21 \\
(2003)\end{array}$ & Voluntary & $\begin{array}{l}\text { - Social and } \\
\text { economic facets } \\
\text { - Environmental } \\
\text { themes }\end{array}$ & $\begin{array}{l}\text { Analytic study } \\
\text { of } \\
\text { environmental } \\
\text { management } \\
\text { providing non- } \\
\text { generic } \\
\text { international } \\
\text { regulations. }\end{array}$ & $\begin{array}{l}\text { No real checks } \\
\text { on effects of } \\
\text { environmental } \\
\text { impact on } \\
\text { conduct of } \\
\text { member } \\
\text { companies. }\end{array}$ \\
\hline $\begin{array}{l}\text { U.N. } \\
\text { (Sub- } \\
\text { commission on } \\
\text { the Promotion } \\
\text { and Protection } \\
\text { of Human } \\
\text { Rights) } \\
\text { Norms on the } \\
\text { responsibilities } \\
\text { of } \\
\text { transnational } \\
\text { corporations } \\
\text { and other } \\
\text { business } \\
\text { enterprises } \\
\text { with regard to } \\
\text { human rights } \\
\text { (2003) }\end{array}$ & $\begin{array}{l}\text { Regulatory } \\
\text { approach, } \\
\text { commitment } \\
\text { to monitor } \\
\text { multinationals } \\
\text { and take legal } \\
\text { action. }\end{array}$ & $\begin{array}{l}\text { - Non- } \\
\text { discrimination } \\
\text { - Protection of } \\
\text { civilians and } \\
\text { rules of war } \\
\text { - Use of security } \\
\text { forces } \\
\text { - Workers' rights, } \\
\text { corruption } \\
\text { - Consumer } \\
\text { protection } \\
\text { - Human rights, } \\
\text { economic, social, } \\
\text { and cultural } \\
\text { rights } \\
\text { - Environment } \\
\text { and the rights of } \\
\text { indigenous } \\
\text { peoples }\end{array}$ & $\begin{array}{l}\text { May be the } \\
\text { start point for } \\
\text { an } \\
\text { independent } \\
\text { monitor of } \\
\text { multinationals. }\end{array}$ & $\begin{array}{l}\text { Norms are still } \\
\text { very recent, } \\
\text { strongly } \\
\text { opposed by } \\
\text { multinationals } \\
\text { and Chambers } \\
\text { of Commerce }\end{array}$ \\
\hline
\end{tabular}

In a similar manner, the European Union has established corporate guidelines by drafting the Green Paper entitled 'Promoting a European Framework for Corporate Social Responsibility (CSR) ${ }^{23}$. In this document, the European Commission helps corporations to understand the various types of responsibility by identifying an:

- internal dimension with reference to employees, shareholders, and responsible environmental practices for managing natural resources used in production;

- external dimension that involves the local community as well as a wide range of interested parties: business partners, suppliers, customers, public authorities, non-governmental organisations, etc. 
By defining corporate social responsibility as 'a concept whereby companies integrate social and economic concerns in their business operations and in their interaction with their stakeholders on a voluntary basis', the EU expresses its vision and concerns (greatly influenced by Europe's expansion to 25 nations), based primarily on: 'voluntary participation by companies', 'extension of CSR to small and medium companies' and, above all, 'the primacy of social relations with respect to work and employment ${ }^{24}$. The following table describes transnational initiatives at the European level (Table 2).

Table 2: Supranational Initiatives at the EU Level

\begin{tabular}{|c|c|c|c|c|}
\hline INITIATIVE & APPROACH & $\begin{array}{l}\text { CONTENTS, } \\
\text { PRINCIPLES, } \\
\text { RULES }\end{array}$ & $\begin{array}{l}\text { STRONG } \\
\text { POINTS }\end{array}$ & \begin{tabular}{|l|} 
WEAK \\
POINTS
\end{tabular} \\
\hline $\begin{array}{l}\text { European } \\
\text { Commission } \\
\text { Green Paper } \\
\text { (2001) }\end{array}$ & Voluntary & $\begin{array}{l}\text { Indication of } \\
\text { areas for } \\
\text { corporate } \\
\text { initiatives: } \\
\text { - internal } \\
\text { dimension } \\
\text { (management of } \\
\text { human } \\
\text { resources, } \\
\text { worker health } \\
\text { and safety, } \\
\text { adaptation to } \\
\text { transformation, } \\
\text { management of } \\
\text { environmental } \\
\text { impact and } \\
\text { natural } \\
\text { resources) } \\
\text { - external } \\
\text { dimension (local } \\
\text { communities, } \\
\text { business } \\
\text { partners, } \\
\text { suppliers and } \\
\text { consumers, } \\
\text { human rights; } \\
\text { environmental } \\
\text { concerns at the } \\
\text { planetary level) } \\
\text { - Indication of } \\
\text { strategies for } \\
\text { making } \\
\text { voluntary } \\
\text { participation in }\end{array}$ & $\begin{array}{l}\text { - Analysis of } \\
\text { all aspects of } \\
\text { CSR. } \\
\text { - Involvement } \\
\text { of a large } \\
\text { number of } \\
\text { stakeholders. } \\
\text { - Creation of a } \\
\text { forum that } \\
\text { could have } \\
\text { formed the } \\
\text { basis for a } \\
\text { regulatory } \\
\text { approach. }\end{array}$ & $\begin{array}{l}\text { - No } \\
\text { effectiveness } \\
\text { assessment of } \\
\text { policies } \\
\text { enacted. }\end{array}$ \\
\hline
\end{tabular}




\begin{tabular}{|c|c|c|c|c|}
\hline & & $\begin{array}{l}\text { socially } \\
\text { responsible } \\
\text { initiatives more } \\
\text { attractive for } \\
\text { corporations. } \\
\end{array}$ & & \\
\hline $\begin{array}{l}\text { European } \\
\text { Parliament } \\
\text { Resolution to } \\
\text { regulate } \\
\text { multinational } \\
\text { companies } \\
(2002)\end{array}$ & $\begin{array}{l}\text { Voluntary, } \\
\text { integrated with } \\
\text { regulatory } \\
\text { approach }\end{array}$ & $\begin{array}{l}\text { Requests the } \\
\text { European } \\
\text { Commission to } \\
\text { require } \\
\text { multinationals } \\
\text { to present: } \\
\text { - a social and } \\
\text { environmental } \\
\text { report; } \\
\text { - a European } \\
\text { social label for } \\
\text { product } \\
\text { certification; } \\
\text { - a blacklist of } \\
\text { companies } \\
\text { guilty of } \\
\text { corruption. }\end{array}$ & $\begin{array}{l}\text { - Checks by } \\
\text { independent } \\
\text { bodies, } \\
\text { regulation that } \\
\text { integrates } \\
\text { independent } \\
\text { initiatives of } \\
\text { companies. }\end{array}$ & $\begin{array}{l}\text { - Only a } \\
\text { 'request' and } \\
\text { has not been } \\
\text { implemented } \\
\text { by the } \\
\text { European } \\
\text { Commission. }\end{array}$ \\
\hline $\begin{array}{l}\text { European } \\
\text { Commission } \\
\text { White Paper } \\
\text { (2002) }\end{array}$ & Voluntary & $\begin{array}{l}\text { - Seeks to } \\
\text { persuade } \\
\text { companies to } \\
\text { promote socially } \\
\text { responsible } \\
\text { policies; } \\
\text { - Financial } \\
\text { benefit of } \\
\text { choosing greater } \\
\text { social } \\
\text { responsibility } \\
\text { over the long } \\
\text { term. } \\
\end{array}$ & $\begin{array}{l}\text { - Proper mix } \\
\text { of opposing } \\
\text { positions by } \\
\text { companies } \\
\text { (neoliberal } \\
\text { model) and } \\
\text { unions and } \\
\text { NGOs } \\
\text { (alternative } \\
\text { strategies). }\end{array}$ & $\begin{array}{l}\text { - Does not } \\
\text { implement the } \\
\text { European } \\
\text { Parliament's } \\
\text { resolution. }\end{array}$ \\
\hline $\begin{array}{l}\text { European } \\
\text { Commission } \\
\text { Multi- } \\
\text { Stakeholder } \\
\text { Forum on } \\
\text { Corporate } \\
\text { Social } \\
\text { Responsibility } \\
\text { (2002) }\end{array}$ & $\begin{array}{l}\text { Multilateral } \\
\text { forum }\end{array}$ & \begin{tabular}{|l|} 
Promotion of \\
social \\
responsibility \\
concept via four \\
roundtables: \\
- knowledge of \\
CSR tools; \\
- promotion of \\
CSR to small \\
and medium \\
companies; \\
- transparency \\
and \\
\end{tabular} & $\begin{array}{l}\text { - Promotes } \\
\text { discussion and } \\
\text { awareness of } \\
\text { CSR; } \\
\text { - Refers to } \\
\text { small and } \\
\text { medium } \\
\text { companies } \\
\text { too. } \\
\text { Clarifies } \\
\text { positions of } \\
\text { all parties } \\
\text { involved. } \\
\end{array}$ & $\begin{array}{l}\text { - Excessive } \\
\text { reliance on } \\
\text { market as } \\
\text { regulator. } \\
\text { - Revealed } \\
\text { major points } \\
\text { of } \\
\text { disagreement } \\
\text { amongst } \\
\text { parties, with } \\
\text { few feasible } \\
\text { solutions. }\end{array}$ \\
\hline
\end{tabular}




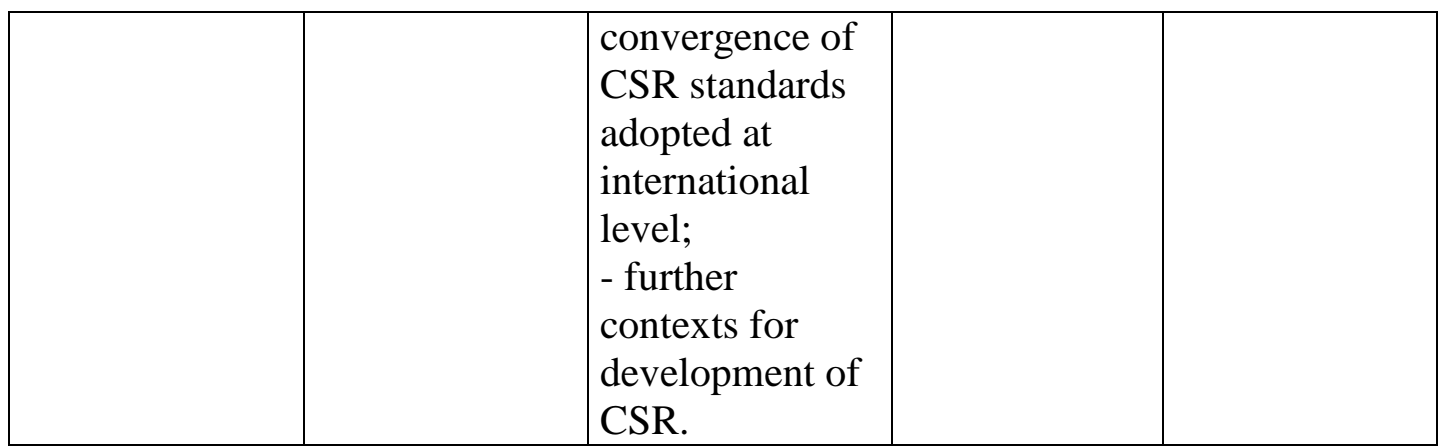

Another interesting transnational contribution is the OECD's Principles of Corporate Governance (Table 3). The Principles help the governments of OECD member and non-member nations to analyse and improve legal, institutional and regulatory conditions with regard to Corporate Governance and to formulate guidelines and proposals to stock exchange authorities, investors, companies and other parties for the purpose of creating an effective Corporate Governance system. The Principles are not mandatory in nature, but rather provide precise Corporate Governance guidelines for lawmakers, governments and companies, and allow member nations to apply them in a way that takes account of different legal, economic and cultural contexts.

With regard to the separation of ownership and control, the Principles do not concentrate only on defining relations between shareholders and management, but also study the problem of relations between holders of majority (controlling) stakes and minority shareholders, as well as the role of other company stakeholders. To manage these relations, particular importance is given to the timely and accurate disclosure of financial information and information on company performance, ownership and governance.

The importance of respecting these guidelines is obvious if one considers that Corporate Governance is one of the main ways to increase efficiency, economic growth and investor loyalty. This is especially true if companies want to attract international funds: if they want to reach a much wider range of investors and attract stable capital over the long term, they will have to implement Corporate Governance systems that are credible and comprehensible abroad, and that respect generally accepted rules of conduct ${ }^{25}$.

Table 3: OECD Principles of Corporate Governance

\begin{tabular}{|l|l|}
\hline PRINCIPLE & DESCRIPTION \\
\hline $\begin{array}{l}\text { I. Ensuring the basis for } \\
\text { an effective corporate } \\
\text { governance framework }\end{array}$ & $\begin{array}{l}\text { The corporate governance framework should promote } \\
\text { transparent and efficient markets, be consistent with the } \\
\text { rule of law and clearly articulate the division of } \\
\text { responsibilities amongst various supervisory, regulatory } \\
\text { and enforcement authorities. }\end{array}$ \\
\hline $\begin{array}{l}\text { II. The Rights of } \\
\text { Shareholders and Key } \\
\text { Ownership Functions }\end{array}$ & $\begin{array}{l}\text { The corporate governance framework should protect } \\
\text { and facilitate the exercise of shareholders' rights. }\end{array}$ \\
\hline $\begin{array}{l}\text { III. The Equitable } \\
\text { Treatment of }\end{array}$ & $\begin{array}{l}\text { The corporate governance framework should ensure the } \\
\text { equitable treatment of all shareholders, including }\end{array}$ \\
\hline
\end{tabular}




\begin{tabular}{|l|l|}
\hline Shareholders & $\begin{array}{l}\text { minority and foreign shareholders. All shareholders } \\
\text { should have the opportunity to obtain effective redress } \\
\text { for the violation of their rights. }\end{array}$ \\
\hline $\begin{array}{l}\text { IV. The Role of } \\
\text { Stakeholders in Corporate } \\
\text { Governance }\end{array}$ & $\begin{array}{l}\text { The corporate governance framework should recognise } \\
\text { the rights of stakeholders established by law or through } \\
\text { mutual agreements and encourage active co-operation } \\
\text { between corporations and stakeholders in creating } \\
\text { wealth, jobs and the sustainability of financially sound } \\
\text { enterprises. }\end{array}$ \\
\hline $\begin{array}{l}\text { V. Disclosure and } \\
\text { Transparency }\end{array}$ & $\begin{array}{l}\text { The corporate governance framework should ensure } \\
\text { that timely and accurate disclosure is made on all } \\
\text { material matters regarding the corporation, including } \\
\text { the financial situation, performance, ownership, and } \\
\text { governance of the company. }\end{array}$ \\
\hline
\end{tabular}

The guidelines point out the need for a company to be 'authentically responsible and dynamic, where dynamism is demonstrated by profitability and by growth considered over a multiyear time-frame, and simultaneously socially committed, where social commitment is demonstrated primarily by an effort to satisfy the legitimate expectations of all stakeholders, beginning with employees and shareholders ${ }^{26}$.

Having analysed the main world and European level supranational initiatives, we can now consider two of their distinctive features:

- the majority of the guidelines and rules are, appropriately, voluntary (not regulatory), and guide, rather than compel, the actions of companies and states in the development of their roles;

- individual Nation-States are not always sufficiently responsive in converting such guidelines into regulations or in effectively enforcing the regulations that they themselves issue ${ }^{27}$.

Clearly, it is pointless to imagine quasi-'hierarchical' models of control and regulation between states and multinationals. Rather, it is better to interpret the globalisation process 'not as something mechanical, but as the result of human actions that translate into behaviours by the parties involved (corporations, governments, institutions, consumers, etc.) and that derive from personal freedom ${ }^{28}$ In this way, the search for balance regarding interests amongst the various parties could become the means by which corporations are no longer viewed - by definition - as opponents, but rather as one of the elements in a global system - just like the Nation-State system and the consumer system.

It is therefore essential to formulate a new profile for corporate responsibility, one to which corporations will willingly adapt, and the respect of which will generate a competitive advantage. In this context, Nation-States and consumers would play the dual role of 'dialectically' contributing to the formulation of rules of conduct and, in case of violation, of reporting, checking, and penalising behaviour that conflicts with guiding principles. Viewed in this way, corporate responsibility combines the unstable and dynamic equilibrium of the global interests of management, shareholders, employees and stakeholders. 


\section{Corporate Responsibility in Managing Equilibriums}

We have seen that under conditions of over-supply, 'a corporation is subject to large-scale socio-environmental pressures. This can be reduced with modern CSR expressing global corporate responsibility in a context of sustainable growth ${ }^{29}$. Therefore, in markets manifesting over-supply, corporate responsibility aims to achieve results (partial and total) characterised by high profitability and efficiency, but with respect for sustainable growth considered to be a priority.

It may therefore be useful to adopt a highly pragmatic interpretation of corporate social responsibility (typical of the American approach and focussed on measuring social responsibility as a corporate intangible essential for success in a global economy), thus defined as 'an action taken by a firm, which the firm chooses to take, that substantially affects an identifiable social stakeholder's welfare ${ }^{30}$.

Relations between corporations and society in global markets have the following critical priorities:

- dealing with different aspects of the social and environmental systems in which they operate;

- competitive pressures linked to the stakeholder system, identifying in advance and solving the social and environmental problems generated by competition.

Therefore, in a global economy, corporate responsibility has to interact with the specific social and environmental aspects of each Nation-State, which consequently are not viewed as local 'differences' but rather as 'elements of market competition', i.e., structural elements for which trends must be known in order to ensure the organisation's local and global growth ${ }^{31}$. This interaction has to concentrate on complex matters such as profitability and the protection of financial equilibriums, respect for ethical codes, environmental concerns and social profiles in general.

\section{Bibliography}

Annan K., The Global Compact. Corporate Leadership in the World Economy, Symphonya. Emerging Issues in Management (symphonya.unimib.it), n. 2, 2002. http://dx.doi.org/10.4468/2002.2.02annan

Bisio L., Corporate Responsibility and Corporate Governance in Europe, Symphonya. Emerging Issues in Management (symphonya.unimib.it), n. 1, 2003 http://dx.doi.org/10.4468/2003.1.09bisio

Bisio L., Global Market and Public Governance in Europe, Symphonya. Emerging Issues in Management (symphonya.unimib.it), n. 1, 2004. http://dx.doi.org/10.4468/2004.1.07bisio

Borja J., Castells M., La città globale. Sviluppo e contraddizioni delle metropoli del terzo millennio, De Agostini, Novara, 2002.

Bowie N.E., Ethical Theory and Business, 6th. ed., Prentice-Hall, Englewood Cliffs, 2001.

Braudel F., Dynamics of capitalism, Il Mulino, Bologna, 1981.

Brondoni S.M., Lambin J. J., Ouverture de 'Brand Equity', Symphonya. Emerging Issues in Management (symphonya.unimib.it), n. 1, 2000-2001. http://dx.doi.org/10.4468/2001.1.01ouverture 
Brondoni S.M., Ouverture de 'Market-Driven Management', Symphonya. Emerging Issues in Management (symphonya.unimib.it), n. 2. 2000-2001.

http://dx.doi.org/10.4468/2001.2.01ouverture

Brondoni S.M., Ouverture de 'Market-Space Management', Symphonya. Emerging Issues in Management (symphonya.unimib.it), n. 1, 2002. http://dx.doi.org/10.4468/2002.1.01ouverture

Brondoni S.M., Ouverture de 'Corporate Responsibility \& Market-Space Competition', Symphonya. Emerging Issues in Management (symphonya.unimib.it), n. 1, 2003. http://dx.doi.org/10.4468/2003.1.01ouverture

Brondoni S.M., Network Culture, Performance and Corporate Responsibility, Symphonya, Emerging Issues in Management (symphonya.unimib.it), n. 1, 2003. http://dx.doi.org/10.4468/2003.1.02brondoni

Caselli C., L’avventura dell'internazionalizzazione. Logiche e strumenti per le imprese, Giappichelli, Turin, 1994.

Castells M., The Information Age: Economy, Society, and Culture: Volume I. The Rise of the Network Society, Oxford, Blackwell, 1996.

Castells M., Il potere delle identità, Università Bocconi Editore, Milan, 2004.

European Commission, Green Paper: Promoting a European framework for corporate social responsibility, Brussels, 2001.

Cooper R.N., The Economics of Interdependence: Economic Policy in the Atlantic Community, McGraw Hill, New York, 1968.

Corniani M., Segmentazione e aggregazione della domanda aziendale, Giappichelli, Turin, 2004.

de Woot P., The Challenges of Economic Globalisation: Business, Competition and Society, Symphonya. Emerging Issues in Management (symphonya.unimib.it), n. 2, 2002. http://dx.doi.org/10.4468/2002.2.03dewoot

Freeman R.E., A Stakeholder Theory of the Corporation, in T.L. Beauchamp, N.E. Bowie (eds.), Ethical Theory and Business, 6th. ed., Prentice-Hall, Englewood Cliffs, 2001, pp. 56-65.

Frooman J., Socially Irresponsible and Illegal Behavior and Shareholder Wealth, Business \& Society, n. 3, 1997. http://dx.doi.org/10.1177/000765039703600302

Garbelli M.E., Over-Supply and Manufacturing Localization, Symphonya. Emerging Issues in Management (symphonya.unimib.it), n. 1, 2002, pp. 145-146. http://dx.doi.org/10.4468/2002.1.10garbelli

Lambin J.J., Strategic Marketing Revisited after September 11, Symphonya. Emerging Issues in Management (symphonya.unimib.it), n. 1, 2002. http://dx.doi.org/10.4468/2002.1.02lambin

Lambin J.J., Market-Driven Management, $4^{\text {th }}$ ed., McGraw Hill, Milan, 2004.

Martinelli A., La democrazia globale. Mercati, movimenti, governi, Università Bocconi Editore, Milan, 2004.

McLuhan M., Understanding Media. The Extension of Man, MIT Press, Cambridge, MA, 1964.

Molteni M., L’impresa tra competitività e responsabilità, Impresa e Stato, October-December, 2003.

Salvioni D.M., Corporate Governance and Global Responsibility, Symphonya. Emerging Issues in Management (symphonya.unimib.it), n. 1, 2003.

http://dx.doi.org/10.4468/2003.1.05salvioni

Wallerstein I., Il sistema mondiale dell'economia moderna, Il Mulino, Bologna, 1974-1989. 


\section{Notes}

${ }^{1}$ For example, F. Braudel's historical studies (1981), I. Wallerstein's world economic approach (1974-1989), the M. McLuhan's sociological/global village interpretation (1964), R. N. Cooper's political study of international interdependence (1968), and J. J. Lambin's (2004) and S. M. Brondoni's (2000-1) theory of Market-Driven Management.

${ }^{2}$ Martinelli A., La democrazia globale. Mercati, movimenti, governi, Università Bocconi Editore, Milan, 2004, p. 1-2.

3 Borja J., Castells M., La città globale. Sviluppo e contraddizioni delle metropoli del terzo millennio, De Agostini, Novara, 2002, p. 15.

${ }^{4}$ Castells M., The Information Age: Economy, Society, and Culture: Volume I. The Rise of the Network Society, Oxford, Blackwell, 1996.

${ }^{5}$ de Woot P., The Challenges of Economic Globalisation: Business, Competition and Society, Symphonya. Emerging Issues in Management (symphonya.unimib.it), n. 2, 2002.

${ }^{6}$ Brondoni S.M., Lambin J. J., Ouverture de 'Brand Equity', Symphonya. Emerging Issues in Management (symphonya.unimib.it), n. 1, 2000-2001.

${ }^{7}$ In markets with over-supply (where products are increasingly sophisticated but quickly made obsolete by easy imitation), there has arisen an economy of intangible supply and business that, on the one hand, emphasises the role of multimarket and multibusiness companies and, on the other, reduces the weight of competition in the industry. Brondoni S.M., Ouverture de 'Market-Driven Management', Symphonya. Emerging Issues in Management (symphonya.unimib.it), n. 2. 20002001

${ }^{8}$ According to Market-Space Competition logic, space is no longer a datum, i.e., a known and stable element of the decision-making process, but instead a competitive factor with a profile that is configured and changes due to the actions/reactions of businesses and governments. Brondoni S.M., Ouverture de 'Market-Space Management', Symphonya. Emerging Issues in Management (symphonya.unimib.it), n. 1, 2002.

9 Brondoni S.M., Ouverture de 'Market-Space Management', Symphonya. Emerging Issues in Management (symphonya.unimib.it), n. 1, 2002.

${ }^{10}$ This occurred in Hungary in 2002, when 'IBM, after operating in the country for seven years, fired 3,700 employees from its hard disk factory in Székesfehérvàr and transferred its entire production to China. And according to local newspapers, Philips is about to do likewise' (Hungary risks delocalisation, Il Sole 24 Ore, 29 November 2002).

${ }^{11}$ Garbelli M.E., Over-Supply and Manufacturing Localization, Symphonya. Emerging Issues in Management (symphonya.unimib.it), n. 1, 2002.

12 de Woot P., The Challenges of Economic Globalisation: Business, Competition and Society, Symphonya. Emerging Issues in Management (symphonya.unimib.it), n. 2, 2002, p. 23-24.

${ }^{13}$ Salvioni D.M., Corporate Governance and Corporate Responsibility, Symphonya. Emerging Issues in Management (symphonya.unimib.it), n. 1, 2003.

${ }^{14}$ Salvioni D.M., Corporate Governance and Corporate Responsibility, Symphonya. Emerging Issues in Management (symphonya.unimib.it), n. 1, 2003.

15 Brondoni S.M., Ouverture de 'Corporate Responsibility \& Market-Space Competition', Symphonya. Emerging Issues in Management (symphonya.unimib.it), n. 1, 2003.

${ }^{16}$ Lambin J.J., Strategic Marketing Revisited after September 11, Symphonya. Emerging Issues in Management (symphonya.unimib.it), n. 1, 2002

${ }^{17}$ Bisio L., Corporate Responsibility and Corporate Governance in Europe, Symphonya. Emerging Issues in Management (symphonya.unimib.it), n. 1, 2003. 
${ }^{18}$ Brondoni S.M., Ouverture de 'Market-Space Management', Symphonya. Emerging Issues in Management (symphonya.unimib.it), n. 1, 2002.

${ }^{19}$ See Corniani M., Segmentazione e aggregazione della domanda aziendale, Giappichelli, Turin, 2004.

${ }^{20}$ See also: Global Market and Public Governance in Europe, Symphonya. Emerging Issues in Management (symphonya.unimib.it), n. 1, 2004, and Castells M.,. 'Il potere delle identità', Università Bocconi Editore, Milan, 2004.

21 The IOL's tripartite declaration on multinationals and social policy regarding freedom of association, abolition of forced labour, non-discrimination, and elimination of child labour (1997/2000), and the OECD's Principles for multinationals (2000) point in the same direction.

22 Annan K., The Global Compact. Corporate Leadership in the World Economy, Symphonya. Emerging Issues in Management (symphonya.unimib.it), n. 2, 2002.

${ }^{23}$ The EU's 'Green Papers' do not have regulatory value, but rather serve as strategic guidelines for dialogue. After full discussion, they are converted into final documents called 'White Papers'. Furthermore, the concepts and guidelines contained in White Papers are then implemented in national and regional legislation of Member States.

${ }^{24}$ Note that this vision puts environmental sustainability (of primary importance for CSR at American multinationals) and the pursuit of co-makership equity/non equity business and research relationships (the basis of CSR for 'Japan/China Based' companies), in second place. Brondoni S.M., Network Culture, Performance and Corporate Responsibility, Symphonya, Emerging Issues in Management (symphonya.unimib.it), n. 1, 2003.

${ }^{25}$ Bisio L., Corporate Responsibility and Corporate Governance in Europe, Symphonya. Emerging Issues in Management (symphonya.unimib.it), n. 1, 2003.

${ }^{26}$ Molteni M., 'L'impresa tra competitività e responsabilità', p. 24, Impresa e Stato, OctoberDecember 2003.

${ }^{27}$ For example: some measures pass through one or two legislatures until they are adopted, all too often subject to 'mediation' rather than adaptation to local situations, and not always conforming to the schemes proposed by supranational bodies. Likewise, the ritualism of certain controls by the public administration serve more to satisfy a bureaucratic obligation than to achieve a result in terms of output or outcome.

28 Caselli C., (1994), 'L'avventura dell'internazionalizzazione. Logiche e strumenti per le imprese', Giappichelli, Turin.

29 Annan K., The Global Compact. Corporate Leadership in the World Economy, Symphonya. Emerging Issues in Management (symphonya.unimib.it), n. 2, 2002.

${ }^{30}$ See J. Frooman, Socially Irresponsible and Illegal Behavior and Shareholder Wealth, Business \& Society, n. 3, 1997, pp. 221-249; R.E. Freeman, A Stakeholder Theory of the Corporation, T.L. Beauchamp, N.E. Bowie (eds.), Ethical Theory and Business, 6th. ed., Prentice-Hall, Englewood Cliffs, 2001, pp. 56-65.

31 Brondoni S.M., Network Culture, Performance and Corporate Responsibility, Symphonya, Emerging Issues in Management (symphonya.unimib.it), n. 1, 2003. 